\title{
Reduced Rate of Fat Oxidation: A Metabolic Pathway to Obesity in the Developing Nations
}

\author{
A. ROBERTO FRISANCHO* \\ Department of Anthropology and Center for Human Growth and Development, University of Michigan, \\ Ann Arbor, Michigan
}

\begin{abstract}
The purpose of this article is to document the metabolic and environmental factors associated with the increased frequency of obesity in the developing nations. While the prevalence of obesity in the developed countries is caused by the increased consumption of caloriedense foods, in the developing nations, because obesity coexists with undernutrition, additional factors are necessary to account for it. The evidence suggests that an important contributing factor for obesity in the developing nations is a reduced fat oxidation and increased metabolism of carbohydrate that has been brought about by the chronic undernutrition experienced during prenatal and postnatal growth. This shift toward a preferential metabolic use of carbohydrate rather than of fat results in an increased deposition of body fat. This tendency, along with the general decrease of energy expenditure in physical activity associated with urbanization, and the culturally mediated acceptance of fatness leads to obesity among populations from the developing nations. A joint effect of these factors is that in the developing nations obesity is associated with short stature resulting from developmental undernutrition, while in the developed countries obesity is associated with tall stature. It is hoped that future research will address the mechanisms whereby undernutrition increases the tendency toward obesity. Understanding how to modify fat oxidation could affect our ability to prevent weight gain among undernourished populations of the developing nations. Therefore, future research on the interaction of undernutrition and the development of obesity is of prime importance for anthropology concerned with the origins of human variability. Am. J. Hum. Biol. 15:522-532, 2003.2003 Wiley-Liss, Inc.
\end{abstract}

Obesity in the developed nations has become a major public health problem. Likewise in developing nations obesity is reaching epidemic proportions. Epidemiological studies have attributed the high prevalence rates of obesity of developed nations to the excess intake of dietary fat (Bray and Popkin, 1998). Hence, it is assumed that obesity in the developing nations is related to the high proportion of energy derived from dietary fat. However, comparisons of both diets and the prevalence of obesity between affluent and poor countries do not support such an explanation. Furthermore, in the developing nations obesity coexists with malnutrition (ACC/SCN, 2000). Therefore, the increasing prevalence of obesity among populations of the developed nations requires an additional explanation. I postulate that an important factor contributing to obesity in the developing nations is a reduced fat oxidation and increased metabolism of carbohydrate that has been brought about by the chronic undernutrition experienced during prenatal and postnatal growth. This shift towards a preferential metabolic use of carbohydrate rather than of fat results in an increased deposition of body fat and, along with the general decrease in physical activity, leads to obesity among populations from the developing nations.

\section{EPIDEMIOLOGICAL EVIDENCE}

Despite the fact that undernutrition continues to be a major problem for developing nations, there is growing evidence that the prevalence of overweight and obesity is increasing in these populations. Many studies have documented the rapid increase in overweight and obesity in childhood and adults (WHO, 1998; Wang et al., 2002; Popkin and Doak, 1998; de Onis and Blössner, 2000; Martorell et al., 2000). The prevalence rates for overweight and obese women are different in each region, with the Middle East, Central, and Eastern Europe having

*Correspondence to: Dr. A. Roberto Frisancho, Department of Anthropology, 1020 L.S.A. Bldg., University of Michigan, Ann Arbor, MI 48109-1382. E-mail: arfrisan@ umich.edu

Received 7 November 2002; Revision received 16 March 2003; Accepted 18 March 2003

Published online in Wiley InterScience (www.interscience. wiley.com). DOI: 10.1002/ajhb.10191 
higher prevalence rates (ACC/SCN, 2000). For example, while the prevalence of excess weight in women (body mass index $>30.00 \mathrm{~kg} / \mathrm{m}^{2}$ ) in Egypt and Namibia is quite low in Latin American the frequency of excess weight reaches $10 \%$. At this rate, by the year 2010 the prevalence of excess weight in these countries will approach those of the USA. Several factors have been implicated to account for the increased prevalence of weight in developing countries, including: socioeconomic factors and change in dietary habits and activity patterns, previous exposure to undernutrition, and cultural background.

\section{SOCIOECONOMIC CHANGE: DIETARY HABITS AND ACTIVITY PATTERNS}

In general, and in all countries, the prevalence of overweight is greater in urban than in rural areas (ACC/SCN, 2000). The increased prevalence of overweight in urban areas is probably related to the changes in economic development. Among some of the developing nations such as Brazil and China there have been marked shifts in the economies and in social welfare (Wang et al., 2002; World Bank, 1999; China National Bureau of Statistics, 1999; Mroz and Popkin, 1995; FAO, 1998). Large proportions of the populations of Brazil and China have benefited from improved economic and social conditions. Over the past two decades, the per capita gross domestic product has increased dramatically in Brazil and China. As a consequence of their improved economic status, these populations have shifted toward a more secure food supply and increased dietary intake derived from nutrient-dense and energy-dense food (Wang et al., 2002; World Bank, 1999; China National Bureau of Statistics, 1999; Mroz and Popkin, 1995; FAO, 1998). In addition, the energy expenditure in travel from home to place of work decreased markedly while inactive leisure time increased dramatically (World Bank, 1999; Popkin, 1998, 1999). For example, ownership and use of television sets has increased remarkably in Brazil and China. Interestingly (Fig. 1), in the developing countries such as Brazil and China the prevalence of overweight is greater in the high-income rather than low-income groups, while in the United States it is the opposite.

\section{CHRONIC EXPOSURE TO UNDERNUTRITION}

Experimental studies with rats indicate that male offspring of rats that were foodrestricted during the first 2 weeks of pregnancy and then allowed to eat freely (Jones and Friedman, 1982; Jones et al., 1984; Jones et al., 1986), became obese by 5 weeks of age (Fig. 2). Studies of pigs who were growthretarded and protein-deficient during weaning demonstrated that they became quite fat

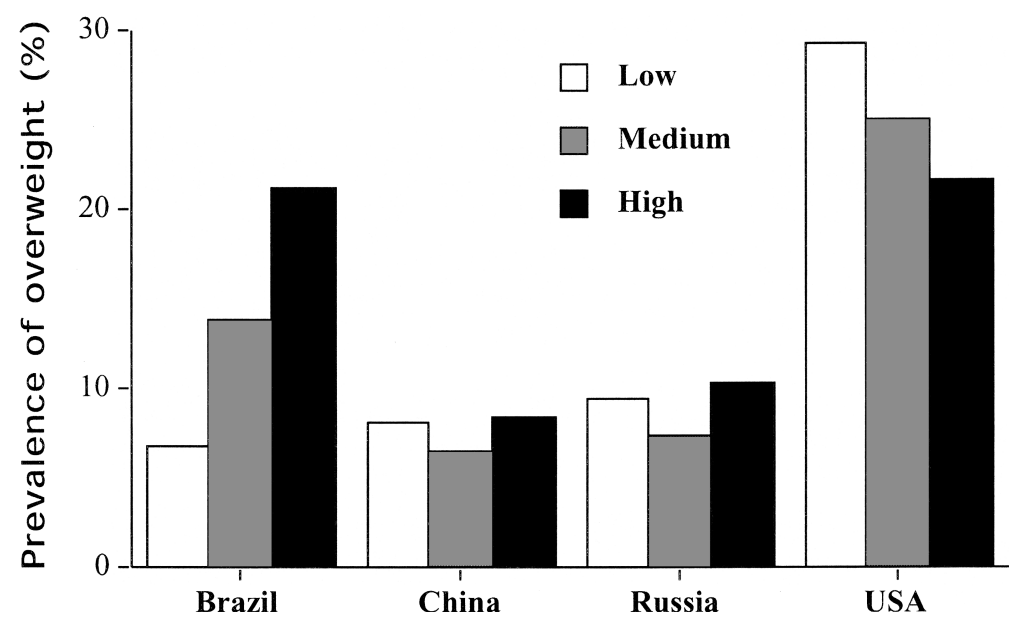

Fig. 1. Relation between per capita household income and the prevalence of overweight ( $>2 \mathrm{Z}$ score of weight-forheight of international reference). Data from Wang et al., 2002. 


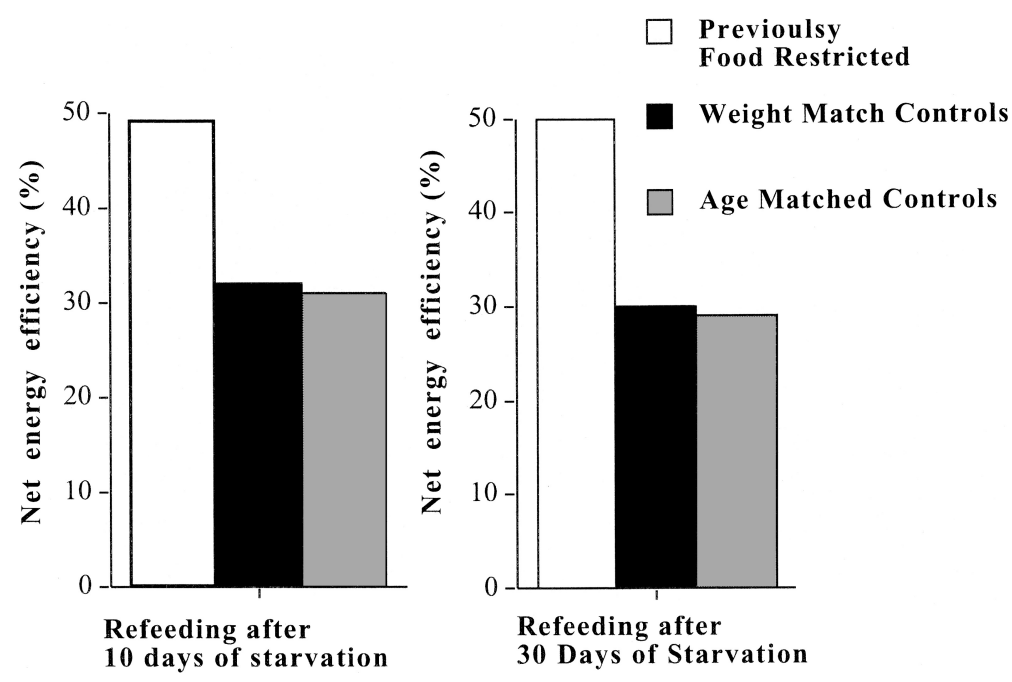

Fig. 2. Changes in energy efficiency (defined as low energy expenditure per unit of work) following dietary deprivation in rats. Data from Dulloo and Girardier, 1990.

later in life (McCance and Widdowson, 1974). Similar investigations in rats who were foodrestricted showed an elevated efficiency of energy utilization and a preferential accumulation of fat (Dulloo and Girardier, 1990).

Analyses of survivors of the Dutch famine of World War II found that the Dutch army draftees whose mothers had been deprived of food in the first two trimesters of pregnancy had a greater incidence of obesity than did the general population (Ravelli et al., 1976). These differences persisted when the sample was divided by occupation. Supplementation studies conducted on growth-retarded children (with an average age of 9.0 years) from Bundi, Papua New Guinea indicate that protein and calorie supplementation for a 13-week period did not have a major effect on growth in body length (Malcolm, 1970). In contrast, supplementation did have a significant effect on increasing subscapular skinfold thickness (Malcolm, 1970). These data would suggest that both protein and energy provided some extra energy, which was used for fat deposition rather than growth. This conclusion is supported by recent studies conducted among Jamaican children. In these studies, nutritional supplementation (calories and protein) of growth-retarded children (with an average age of 18.5 months) for 1 year did not have a major effect on growth in length or mid-upper arm circumference (Walker et al., 1991), but did have a signifi- cant effect on increasing skinfold thickness. Similarly, Spurr and colleagues research showed the independent effects of caloric (on body fat) and protein (on body cell and muscle mass) repletion after severe undernutrition (Spurr and Reina, 1988; Barac-Nieto et al., 1979). Furthermore, Spurr (1990) demonstrated the limited beneficial effects on daily physical activities of nutritional supplementation of chronically undernourished compared to normal children.

In summary, the available evidence suggests that among previously undernourished individuals there is a tendency to increase the accumulation of fat. As a result of this tendency to accumulate body fat rather than use the energy for linear growth, chronic undernutrition coexists with overweight in children previously undernourished populations. In Latin America, chronically undernourished children coexist with overweight children (Fig. 3), which suggests that the etiology of obesity is not due to only an excess dietary intake, but probably is related to activation of energy-sparing mechanisms.

\section{ENERGY-SPARING MECHANISMS: REDUCTION IN EE}

The Minnesota experimental studies of semistarvation showed that 6 months and 1 year of severe energy restriction in 32 lean men led to a marked reduction in energy 


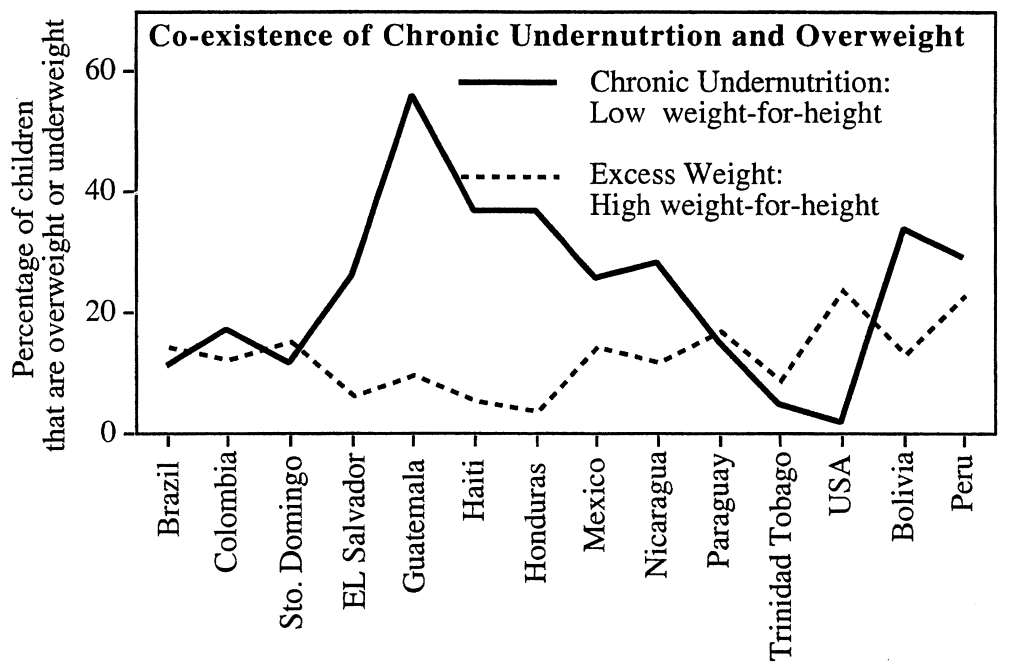

Fig. 3. Coexistence of undernutrition and overweight in Latin American children. Data from ACC/SCN, 2000.

expenditure (EE). This was due to a reduction in both physical activity and in the resting metabolic rate (RMR), which decreased not only in absolute terms (39\%) but also when expressed per kilogram of metabolically active tissue (16\%). Analysis of subjects who were refed after the starvation indicate that weight regain was due to increased fat accumulation (Keys et al., 1950; Grande et al., 1958). Reanalysis of data from the Minnesota experiment revealed that the reduction in the sleeping resting metabolic rate (SMR) in response to food deprivation is related to the activation of an autoregulatory feedback system in which signals from the depleted fat stores suppress thermogenesis, which results in decreased RMR and a specific metabolic component favoring fat storage (Keys et al., 1950; Dulloo et al., 1997; Dulloo and Jacquet, 1998).

Investigations of nonobese cyclical dieters (having dieted for $\geq 7-10$ days four times/ year) indicate that cyclical dieters had a significantly lower energy expenditure (per unit of body weight) in treadmill exercise compared to controls with a similar calorie intake (Manore, 1991). In other words, nonobese chronic dieters with similar lean body weights (but more body fat) use less energy to perform their daily activities than do nondieters (Manore, 1991). Likewise, indi-viduals confined inside Biosphere 2 (Weyer et al., 2000) for 2 years with a markedly restricted food supply during most of the time exhibited marked weight loss and an increase in fat mass when their body weight reverted to preentry values (Weyer et al., 2000).

In summary, these findings suggest that humans exposed to life-threatening undernutrition (such as after several months of semistarvation) and moderate energy restriction that can be sustained over years adapt through a reduction in EE and preferential accumulation of body fat. This form of energy conservation is a biologically meaningful mechanism in the face of dangerously and moderately low energy supplies that has been referred to as metabolic adaptation and "poststarvation obesity" (Keys et al., 1950). In other words, in the face of food energy deficits the organism increases metabolic efficiency by suppressing thermogenesis and hence reducing the rate at which the body's tissues are being depleted. The survival value of such an energy-sparing regulatory process that limits tissue depletion during food scarcity is obvious (Jenike, 1996). Furthermore, these findings indicate that exposure to undernutrition even during adulthood accelerates the replenishment of fat stores during refeeding and thereby increasing the risk of obesity.

\section{ENERGY-SPARING MECHANISMS: INCREASED METABOLISM OF CARBOHYDRATES}

The ratio of carbon dioxide production to oxygen consumption, known as the 


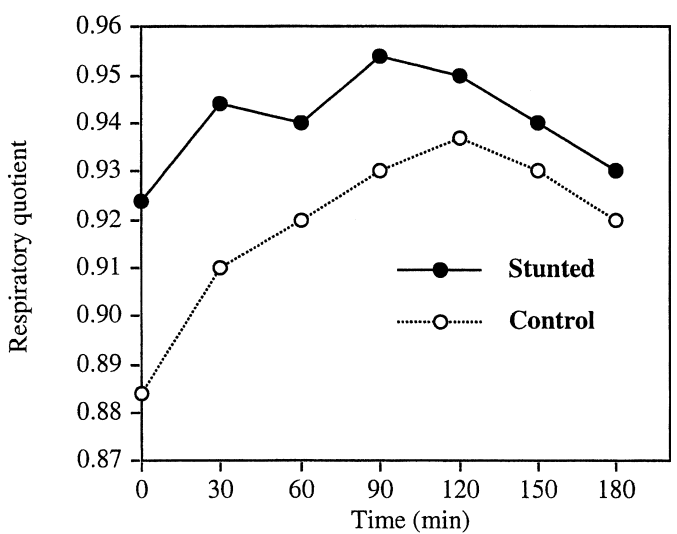

Fig. 4. Increased respiratory quotient associated with stunting in children from Brazil. Adapted from: Hoffman et al., 2000 .

respiratory quotient (RQ), under steady fasting and resting conditions indicates the relative proportion of carbohydrate or fat that is being metabolized. An RQ that is close to 1.0 is taken to indicate that the material being used is chiefly carbohydrate-one around 0.70 indicates that it is mainly fat, while one around 0.80 would indicate that the material being used is chiefly protein (which occurs only under starvation). That is, the higher the $R Q$, the higher the metabolism of carbohydrate. Conversely, the lower the RQ the higher the metabolism of fat.

As illustrated in Figure 4, the respiratory quotient is significantly higher in the nutritionally stunted than in the control Brazilian children. As a result of this difference, the nutritionally stunted children under fasting conditions (Table 1) derived about $25 \%$ of the energy from the oxidation of fat, while the nonstunted controls derived more than $34 \%$ (Hoffman et al., 2000). This finding suggests that a reduced fat oxidation is associated with a negative developmental nutritional experience.

Studies of dietary composition indicate that alterations in substrate oxidation are important contributors to the development of obesity (Flatt, 1987; Seidell et al., 1992; Ravussin and Swinburn, 1993; Felber et al., 1981; Schutz et al., 1992; Froidevaux et al., 1992; Lean and James, 1988; Zurlo et al., 1988; Rueda-Maza et al., 1996; Astrup et al., 1994; Larson et al., 1995; Ravussin and Smith, 2002). Longitudinal studies indicate that a low oxidation of fat (high RQ) in the fasting state is a significant predictor of substantial weight gain in nonobese white men (Seidell et al., 1992). Studies in postobese subjects indicate that reduced fat oxidation is related to subsequent body weight gain (Schutz et al., 1992; Froidevaux et al., 1992; Lean and James, 1988). Similarly, subjects failing to maintain body weight reduction have lower fat oxidation than those succeeding in keeping their weight down (Froidevaux et al., 1992). Likewise, obese prepubertal children who were fed a mixed carbohydrate diet had a significantly greater oxidation of exogenous carbohydrate than their lean counterparts (Rueda-Maza et al., 1996). Evaluations of 24-hour RQ in Pima Indians fed a weight maintenance diet found that low fat oxidation was associated with subsequent weight gain (Zurlo et al., 1988). Furthermore, the low fat oxidation was aggregated in families.

In summary, these findings suggest that increased adiposity is related to a certain extent to a preferential oxidation of carbo-

TABLE 1. Fasting respiratory quotient (RQ) and substrate oxidation in control and stunted children from Brazil ${ }^{1}$

\begin{tabular}{lcc}
\hline Condition & $\begin{array}{c}\text { Control } \\
(\mathrm{n}=30)\end{array}$ & $\begin{array}{c}\text { Stunted } \\
(\mathrm{n}=28)\end{array}$ \\
\hline $\mathrm{RQ}$ & $0.89 \pm 0.007$ & $0.92 \pm 0.009^{*}$ \\
$\begin{array}{l}\text { Nonprotein RQ } \\
\text { Carbohydrate oxidation } \\
\quad \% \text { of energy expenditure) }\end{array}$ & $\begin{array}{c}0.90 \pm 0.009 \\
66 \pm 2\end{array}$ & $\begin{array}{c}0.94 \pm 0.009^{*} \\
75 \pm 2^{*}\end{array}$ \\
$\begin{array}{l}\text { Fat oxidation } \\
\quad \% \text { of energy expenditure) }\end{array}$ & $34 \pm 2$ & $25 \pm 2^{*}$ \\
\hline
\end{tabular}

$* P<0.05$.

${ }^{1}$ Adapted from Hoffman et al., 2000. 
hydrate rather than fat. Impaired fat oxidation will tend to cause increased fat deposition over time, since the oxidation of $1 \mathrm{~g}$ of fat is equivalent to $9 \mathrm{kcal}$, while $1 \mathrm{~g}$ of carbohydrate is equivalent to $4 \mathrm{kcal}$. Experimental studies indicate that when the amount of dietary fat was increased, increasing the level of physical activity to 1.8 times the RMR accelerated the oxidation of fat, but under sedentary conditions (1.4 times the RMR) there was no change in the oxidation of fat (Smith et al., 2000). Therefore, the tendency to store fat will be enhanced in an environment where activity is low. Since one of the consequences of urbanization in the developing nations has been a decrease in physical activity, the reduction of fat oxidation is probably also related to the low level of physical activity that characterizes populations in transition from rural to urban environment.

\section{UNCERTAINTY OF FOOD SUPPLY AND BINGE EATING}

Research on disorders of eating behavior have found that undereating predisposes to binge eating (Callaway, 1988) and that binge eating correlates with adult weight gain and obesity (Hays et al., 2002). In the Minnesota starvation experiment (Keys et al., 1950; Dulloo et al., 1997) after cessation of the semistarvation regimen some of the subjects exhibited a disproportionate increase in appetite and gained $\sim 5 \%$ more weight than before the experiment. Ethnographic observations of hunter-gatherers indicate uncertainty of food supply is associated with binge eating (Holmberg, 1950). For example, among the nomads of eastern Bolivia, whose supply of food was rarely abundant and always insecure, when food becomes available the hunters go on a binge and gorge themselves, consuming during 24 hours as much as 30 pounds of peccary meat (Holmberg, 1950). Likewise, once large game is obtained, the Ache huntergatherers from Paraguay will go on a binge and gorge themselves to the extent that they will lie down and go to sleep (Hurtado and Hill, 1991; Hill and Hurtado, 1996). The increased appetite or so-called "delayed hunger" that is exhibited by many South American impoverished individuals that are exposed to positive conditions probably represents a compensatory adaptation to the possibility of uncertainty of food supply that is likely to occur under conditions of poverty (Dingemans et al., 2002).

In summary, the available experimental and epidemiological evidence suggests that exposure to undernutrition, especially during development, induces the activation of energy-conserving mechanisms and improvement in the efficiency of energy utilization. Therefore, after exposure to dietary restriction individuals are more likely to become fatter than before. Recent studies done in calorimetry chambers have found that variability in nonexercise activity thermogenesis (NEAT) or "fidgeting" accounted for nearly 10-fold differences in fat storage that occurred among individuals (Levine et al., 1999, 2000). However, the extent to which variability in NEAT accounts for the increased risk of obesity among previously undernourished populations is not known and awaits future research.

\section{CULTURAL BACKGROUND}

Since the Paleolithic age, as shown by the so-called "Venus" figurines, humans have preferred fatness. This is evident among contemporary societies, in Renaissance and classic art, and in the contemporary vocabulary. Ethnographic analyses indicate that out of 300 anthropological societies, $81 \%$ considered as desirable and attractive a woman whose characteristics included being "plump" or "filled out" (Brown and Konner, 1987). Because fatness was the primary criterion of beauty, traditional marriage preparation of Nigerian girls included up to 2 years of seclusion in "fattening huts" (Malcom, 1925). Similarly, among the Havasupai of the American Southwest and the Tarahumara of northern Mexico, fat thighs and legs were considered essential to beauty (Smithson, 1959; Bennett and Zingg, 1935). Even among contemporary populations such as the Kipsigis from Kenya, fatter brides (as well as early-maturing brides) demand significantly higher bridewealth payments than do their leaner, late-blooming peers (Borgerhoff, 1988). In males from the Massas, increased fatness is also associated with prestige. The Massas from northern Cameroon frequently participate in the "Guru Walla" fattening tradition aimed at prestige acquisition, which includes a 2-month overfeeding representing twice or threefold the habitual daily intake (De Garine and Koppert, 1991; Pasquet et al., 1992). 
In economically modernized societies, as shown by the paintings of the "Madona" of Goya (1746-1828), the "Joy of Life" of Matisse (1869-1954), "Mother and Child" of Picasso (1881-1974), etc., fatness in women and children was considered attractive. Prior to the eradication of tuberculosis, fatness was considered an indicator of good health in the United States and fat babies were usually considered healthy. It is only in the last few decades that fat has not been viewed as desirable in the US. However, in many other populations the term fat is still used in a positive form and may be interpreted as a sign of health and prosperity. In fact, the term "fat cat," which is associated with wealth and power, is said to be a vestige of the idea that fatness is associated with success (Schwartz, 1986). Similarly, studies of Puerto Ricans in the US indicate that being fat does not have the social stigma of obesity given in other populations (Massara, 1989). For this reason, Mexican-Americans use the term "gordura mala" (bad fatness) when describing fatness that is associated with a negative health risk (Ritenbaugh, 1982). The San Antonio Heart study (Haffner et al., 1991; Hazuda et al., 1988) and analyses of the anthropometric data of the Hispanic Health and Nutritional Examination Survey (Pawson et al., 1991) indicate that among Mexican-Americans the maintenance of traditional cultural values was associated with an increase in the incidence of obesity. These findings suggest that levels of fatness in MexicanAmericans, especially women, may reflect cultural preferences toward fatness.

In a previous publication we studied the parent and offspring similarities and differences in body fat of Mexican-American sub- jects derived from the 1982-1984 data from the Hispanic Health and Nutrition Examination Survey (HHANES). Results of this study showed that heavier parents had heavier and fatter children than lean parents. The association between parental heaviness and offspring fatness was greater for mothers than for fathers. When only one parent was obese, the offspring of heavy mothers were two times more likely to become fat than were the offspring of heavy fathers. Thus, parental obesity more than doubles the risk of obesity in children (Table 2, Fig. 5). Hence, the shared environment is an important contributor to the development of obesity.

Analysis of the datasets of the third National Health and Nutrition Examination (NHANES III) survey of 1988-1994 indicate that the dietary energy intake of Mexican-Americans is not higher than those of the other ethnic groups in the United States (Crespo et al., 2001). On the other hand, physical inactivity during leisure time is more prevalent among the Mexican-Americans than the other ethnic groups (Crespo et al., 2001). Specifically, this study showed that: 1) the prevalence of obesity is greater among children who watch 4 or more hours of television a day; 2) girls report engaging in less physical activity than boys; and 3) Mexican-Americans participated less frequently in physical activity than non-Hispanic whites. The observed high association between parental fatness and fatness in children indicates that the influence of shared environmental factors that occur within Mexican-American families rather than genes (Frisancho et al., 2001) is an important contributor to the development of obesity.

TABLE 2. Comparison of the frequency (\%) and relative risk (RR) of offspring becoming fat according to their mother's or father's body mass index category of Mexican-Americans

\begin{tabular}{lccc}
\hline & \multicolumn{2}{c}{ Offspring fatness defined by } \\
\cline { 2 - 4 } By body mass index & BMI (\%) & Sum of 2 skinfolds (\%) & Sum of 4 skinfolds (\%) \\
\hline Obese mother & 30.5 & 28.7 & 27.8 \\
Obese father & 14.6 & 13.7 & 13.7 \\
Relative of risk of becoming fat offspring (RR) & 2.1 & 2.1 & 2.1 \\
Lean mother & 6.0 & 6.6 & 6.2 \\
Lean father & 7.5 & 7.3 & -0.6 \\
Relative of risk of becoming fat offspring (RR) & -0.8 & -0.9 & -0.8 \\
\hline
\end{tabular}

Derived from the datasets of Hispanic Health Examination Survey of 1982-1984 (HHANES). Adapted from Frisancho et al., 2001. 


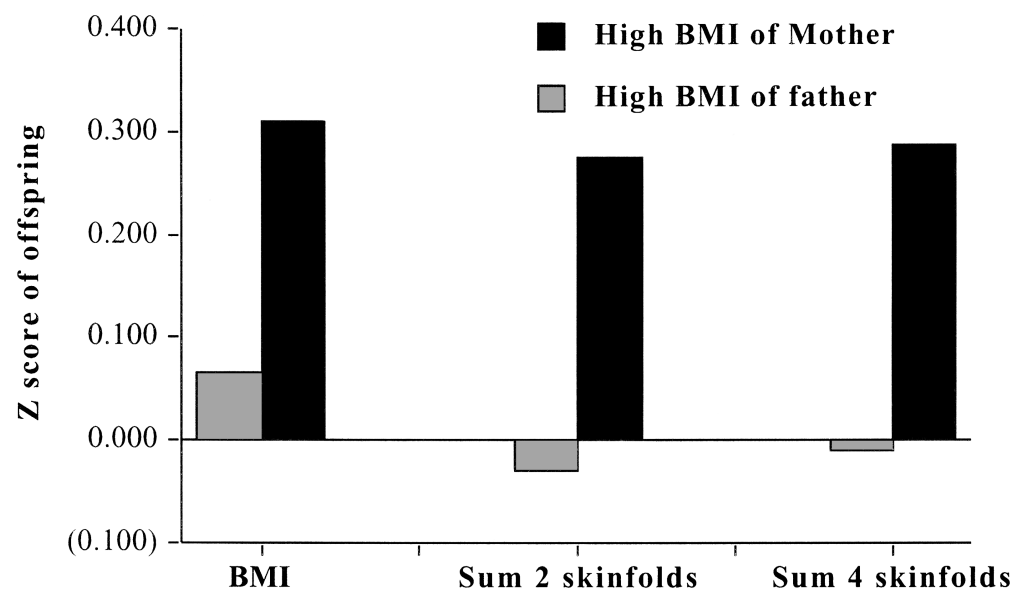

Fig. 5. Comparison of body mass index and sum of two and four skinfold thickness by the body mass index category of the parents of Mexican-Americans. When the mother is heavy (defined by high BMI) the Z scores for BMI and skinfold thickness of the offspring were significantly greater than when the father was heavy. Adapted from: Frisancho et al., 2001.

\section{DEVELOPED NATIONS}

ENVIRONMENTAL FACTORS
${ }^{*}$ High dietary intake of foods rich
in calories and fat
* Low energy expenditure in
physical activity
* Binge eating

Frequent Dietary Restriction:

${ }^{*}$ Reduction in body weight

* Biological and behavioral

energy-conserving meachisms

* Lower total energy requirements

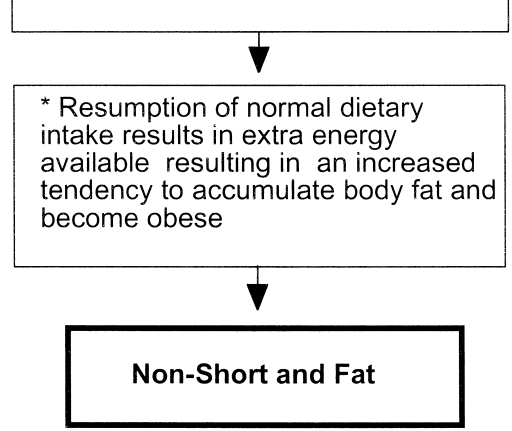

\section{DEVELOPING NATIONS}

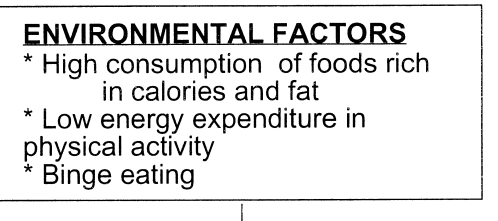

Chronic Undernutrition During
Development:
* Biological and behavioral
energy-conserving meachisms
* Metabolic preference to oxidate
carbohydrates and store fat
leading to overweight
$\downarrow$

* Culturally-mediated acceptance of fat body contributes to the increased risk of obesity.

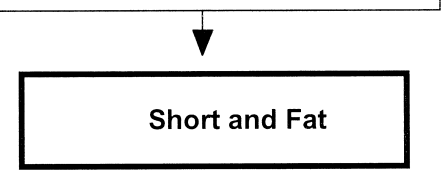

Fig. 6. Schematization of the etiology of obesity in the developed and developing nations.

\section{SUMMARY}

In the developed nations, conspicuous changes in the environment and lifestyle have resulted in increased consumption of food rich in fat, which has been attributed to the escalating rates of obesity. In the developing nations there has also been an 
increase in the availability of food rich in fat, but the fact that the prevalence of obesity coexists with chronic undernutrition calls for an additional explanation. As schematized in Figure 6, exposure to chronic undernutrition during growth and development results in the reduction of fat oxidation and increased metabolism of carbohydrate. This shift towards a preferential metabolic use of carbohydrate rather than of fat results in an increased deposition of body fat, which along with the general decrease of energy expenditure in physical activity associated with urbanization, and the culturally mediated acceptance of fatness, leads to obesity among populations from the developing nations. The joint effect of these factors is that in the developing nations obesity is associated with short stature resulting from developmental undernutrition. On the other hand, in the developed countries obesity is associated with normal stature.

It is hoped that future research will address the mechanisms whereby undernutrition increases the tendency toward obesity. Understanding how to modify fat oxidation could affect our ability to prevent weight gain among undernourished populations of the developing nations. Therefore, future research on the interaction of undernutrition and the development of obesity is of prime importance for anthropology concerned with the origins of human variability. The fact that obesity is a negative risk factor for the incidence of type 2 diabetes (Amos et al., 1997; Zimmet et al., 2001) means that understanding how undernutrition during development increases the risk of obesity during adulthood will also benefit our understanding of the etiology of type 2 diabetes, which is becoming a major public health problem throughout the world.

\section{LITERATURE CITED}

ACC/SCN. 2000. Fourth report on the world nutrition situation. Geneva: ACC/SCN in collaboration with IFPRI.

Amos A, McCarty D, Zimmet P. 1997. The rising global burden of diabetes and its complications: estimates and projections to the year 2010. Diabetic Med 14:S1-S85.

Astrup A, Buemann B, Christensen N, Toubro S. 1994. Failure to increase lipid oxidation in response to increasing dietary fat content in formerly obese women. Am J Physiol 266:E592-599.

Barac-Nieto M, Spurr GB, Lotero H, Maksud MG, Dahners HW. 1979. Body composition during nutritional repletion of severely undernourished men. Am J Clin Nutr 32:981-991
Bennett WC, Zingg RM. 1935. The Tarahumara: an Indian tribe of northern Mexico. Chicago: University of Chicago Press.

Borgerhoff MM. 1988. Kipsigis bridewealth payments. In: Betzig L, Bogerhoff Mulder M, Lairke P, editors. Human reproductive behavior. Cambridge, UK: Cambridge University Press. p 65-82.

Bray GA, Popkin BM. 1998. Dietary fat intake does affect obesity! Am J Clin Nutr 68:1157-1173.

Brown RJ, Konner M. 1987. An anthropological perspective on obesity. In: Wurtman RJ, Wurtman JJ, editors. Human obesity. Ann NY Acad Sci 499:29-46.

Callaway CW. 1988. Biological adaptation to starvation and semistarvation. In: Frankle RT,Yang MU, editors. Obesity and weight control: the health professionals guide to understanding and treatment. Rockville, MD: Aspen. p 97-108.

China National Bureau of Statistics. China statistical yearbook 1999. Beijing: China Statistical Publishing House.

Crespo CJ, Smith E, Andersen RE, Carter-Pokras O, Ainsworth BE. 2000. Race/ethnicity, social class and their relation to physical inactivity during leisure time: results from the Third National Health and Nutrition Examination Survey, 1988-1994. Am J Prevent Med 18:46-53.

Crespo CJ, Smith E, Troiano RP, Bartlett SJ, Macera CA, Andersen RE. 2001. Television watching, energy intake, and obesity in US children: results from the third National Health and Nutrition Examination Survey, 1988-1994. Arch Pediatr Adolesc Med 155:360-365.

de Garine I, Koppert GJA. 1991. Guru, fattening session among the Massa. Ecol Food Nutr 25:1-28.

de Onis M, Blössner M. 2000. Prevalence and trends of overweight among preschool children in developing countries. Am J Clin Nutr 72:1032-1039.

Dingemans AE, Bruna MJ, van Furth EF. 2002. Binge eating disorder: a review. Int $J$ Obes Relat Metab Disord 26:299-307.

Dulloo AG. 1997. Regulation of body composition during weight recovery: integrating the control of energy partitioning and thermogenesis. Am J Clin Nutr 16(Suppl):25-35.

Dulloo AG, Girardier L. 1990. Adaptive changes in energy expenditure during refeeding following lowcalorie intake: evidence for a specific metabolic component favoring fat storage. Am J Clin Nutr 52: 415-420.

Dulloo AG, Jacquet J. 1998. Adaptive reduction in basal metabolic rate in response to food deprivation in humans: a role for feedback signals from fat stores. Am J Clin Nutr 68:599-606.

Dulloo AG, Jacquet J, Girardier L. 1997. Poststarvation hyperphagia and body fat overshooting in humans: a role for feedback signals from lean and fat tissues. Am J Clin Nutr 65:717-723.

FAO (Food and Agriculture Organization). 1998. FAO production yearbook, Rome: Food and Agriculture Organization of the United Nations, FAO statistics series; no. 104.

Felber JP, Meyer HU, Curchod B, Iselin HU, Rousselle J, Maeder E, Pahud P, Jequier E. 1981. Glucose storage and oxidation in different degrees of human obesity measured by continuous indirect calorimetry. Diabetologia 20:39-44.

Flatt JP. 1987. Dietary fat, carbohydrate balance, and weight maintenance: effects of exercise. Am J Clin Nutr 45:296-306.

Frisancho AR, Tanner S, Abrams ET. 2001. Influence of parental obesity on obesity of Mexican-American children. Acta Med Auxol 33:213-217. 
Froidevaux F, Schutz Y, Christin L, Jequier E. 1992. Energy expenditure in obese women before and during weight loss, after refeeding, and in the weight-relapse period. Am J Clin Nutr 57:35-42.

Grande F, Anderson JT, Keys A. 1958. Changes of basal metabolic rate in man in semi-starvation and refeeding. J Appl Physiol 12:230-238.

Haffner SM, Stern MP, Mitchell BD, Hazuda HP. 1991. Predictors of obesity in Mexicans. Am J Clin Nutr 53:1571-76S.

Hays NP, Bathalon GP, McCrory MA, Roubenoff R, Lipman R, Roberts SB. 2002. Eating behavior correlates of adult weight gain and obesity in healthy women aged 55-65 years. Am J Clin Nutr 75:476-483.

Hazuda HP, Haffner SM, Stern MP, Eifler CW. 1988. Effects of acculturation and socioeconomic status on obesity and diabetes in Mexican Americans. Am J Epidemiol 128:1289-1301.

Hill KR, Hurtado AM. 1996. The Ache life history. New York: Aldine de Gruyter.

Hoffman DJ, Sawaya AL, Verreschi I, Tucker KL, Roberts SB. 2000. Why are nutritionally stunted children at increased risk of obesity? Studies of metabolic rate and fat oxidation in shantytown children from São Paulo, Brazil. Am J Clin Nutr 72:702-707.

Holmberg A. 1950. Nomads of the long bow: the Siriono of eastern Bolivia. Smithsonian Institution, Institute of Social Anthropology, Publication No. 10. Washington, DC: US GPO.

Hurtado AM, Hill KR. 1991. Seasonal variation in the diet and sexual division of labor among Hiwi huntergatherers. J. Anthropol Res 46:293-346.

Jenike MR. 1996. Activity reduction as an adaptive response to seasonal hunger. Am J Hum Biol 8:517-534.

Jones AP, Friedman MI. 1982. Obesity and adiposyte abnormalities in offspring of rats undernourished during pregnancy. Science 215:1518-1519.

Jones AP, Simson EL, Friedman MI. 1984. Gestational undernutrition and the development of obesity in rats. J Nutr 114:1484-1492.

Jones AP, Assimon SA, Friedman MI. 1986. The effect of diet on food intake and adiposity in rats made obese by gestational undernutrition. Physiol Behav 37:381-386.

Keys A, Brozek J, Henschel A, Mickelsen O, Taylor HL. 1950. The biology of human starvation. Minneapolis: University of Minnesota Press.

Larson DE, Ferraro RT, Robertson DS, Ravussin E. 1995. Energy metabolism in weight-stable postobese individuals. Am J Clin Nutr 62:735-739.

Lean ME, James WPT. 1988. Metabolic effects of isoenergetic exchange over 24 hours in relation to obesity in women. Int $\mathrm{J}$ Obes 12:15-27.

Levine JA, Eberhardt NL, Jensen MD. 1999. Role of nonexercise activity thermogenesis in resistance to fat gain in humans. Science 283:212-214.

Levine JA, Schleusner SJ, Jensen MD. 2000. Energy expenditure of nonexercise activity. Am J Clin Nutr 72:1451-1454.

Malcolm LA. 1970. Growth and development in New Guinea-a study of the Bundi people of the Madang district. Institute of Human Biology; Papua-New Guinea. Monograph Series No. 1. Australia: Surrey Beatty \& Sons.

Malcom LWG. 1925. Note on the seclusion of girls among the Efik at Old Calabar. Man 25:113-114.

Manore MM, Berry TE, Skinner JS, Carroll SS. 1991. Energy expenditure at rest and during exercise in nonobese female cyclical dieters and in nondieting control subjects. Am J Clin Nutr 54:41-46.
Martorell R, Kettel Khan L, Hughes ML, GrummerStrawn LM. 2000. Overweight and obesity in preschool children from developing countries. Int J Obes Relat Metab Disord 24:959-967.

Massara EB. 1989. Que gordita!: a study of weight among women in a Puerto Rican community. New York: AMS Press.

McCance RA, Widdowson EM. 1974. The determinants of growth and form. Proc R Soc Lond 185:1-17.

Mroz T, Popkin BM. 1995. Poverty and the economic transition in the Russian Federation. Econ Dev Cult Change 44:1-31.

Pasquet P, Brigant L, Froment A, Koppert GA, Bard D, de Garine I, Apfelbaum M. 1992. Massive overfeeding and energy balance in men: the Guru Walla model. Am J Clin Nutr 56:483-490.

Pawson GL, Martorell R, Mendoza FE. 1991. Prevalence of overweight and obesity in U.S. Hispanic populations. Am J Clin Nutr 53:1522S-15228S.

Popkin BM. 1998. The nutrition transition and its health implications in lower-income countries. Public Health Nutr 1:5-21.

Popkin BM. 1999. Urbanization, lifestyle changes and the nutrition transition. World Dev 27:1905-1916.

Popkin BM, Doak CM. 1998. The obesity epidemic is a worldwide phenomenon. Nutr Rev 56:106-114.

Ravelli G, Stein ZA, Susser MW. 1976. Obesity in young men after famine exposure in utero and early infancy. N Engl J Med 295:350-353.

Ravussin E, Swinburn BA. 1993. Metabolic predictors of obesity: cross-sectional versus longitudinal data. Int $J$ Obes 17(Suppl 3):S28-31.

Ritenbaugh C. 1982. Obesity as a culture-bound syndrome. Cult Med Psychiatry 6:347-361.

Rueda-Maza CM, Maffeis C, Zaffanello M, Schutz Y. 1996. Total and exogenous carbohydrate oxidation in obese prepubertal children. Am J Clin Nutr 64: 844-849.

Schutz, Y, Tremblay A, Weinsier RL, Nelson KM. 1992. Role of fat oxidation in the long-term stabilization of body weight in obese women. Am J Clin Nutr 55: 670-674.

Schwartz H. 1986. Never satisfied: a cultural history of diets, fantasies, and fat. New York: Free Press.

Seidell JC, Muller DC, Sorkin JD, Andres R. 1992. Fasting respiratory exchange ratio and resting metabolic rate as predictors of weight gain: the Baltimore Longitudinal Study on Aging. Int J Obes 16:66-74.

Smith SR, de Jonge L, Zachwieja JJ, Roy H, Nguyen T, Rood J, Windhauser M, Volaufova J, Bray GA. 2000. Concurrent physical activity increases fat oxidation during the shift to a high-fat diet. Am J Clin Nutr 72:131-138.

Smithson CL. 1959. The Havasupai woman. Salt Lake City: University of Utah Press.

Spurr GB. 1990. Physical activity and energy expenditure in undernutrition. Prog Food Nutr Sci 14:139-192.

Spurr GB, Reina JC. 1988. Influence of dietary intervention on artificially increased activity in marginally undernourished Colombian boys. Eur J Clin Nutr 42:835-846.

Walker SP, Powell CA, Grantham-McGregor SM, Himes JH, Chang SM. 1991. Nutritional supplementation, psychosocial stimulation, and growth of stunted children: The Jamaican study. Am J Clin Nutr 54:642-648.

Wang Y, Monteiro C, Popkin BM. 2002. Trends of obesity and underweight in older children and adolescents in the United States, Brazil, China, and Russia. Am J Clin Nutr 75:971-977.

Weyer CH, Walford RL, Harper IT, Milner M, MacCallum T, Tataranni PA, Ravussin E. 2000. 
Energy metabolism after 2 years of energy restriction: the Biosphere 2 experiment. Am J Clin Nutr 72: 946-953.

WHO (World Health Organization). 1998. Obesity: preventing and managing the global epidemic-report of a WHO consultation on obesity. Geneva: WHO.

World Bank. 1999. World development indicators. Washington, DC: World Bank (CD-ROM).
Zimmet P, Alberti KGMM, Shaw J. 2001. Global and societal implications of the diabetes epidemic. Nature 414:782-787.

Zurlo F, Lillioja S, Esposito-del Puente A, Nyomba BL, Raz I, Saad MF, Swinburn BA, Knowler WC, Bogardus C, Ravussin E. 1990. Low ratio of fat to carbohydrate oxidation as predictor of weight gain: study of 24-h RER. Am J Physiol 2S9:E650-E657. 